\title{
Spolu, a přece odděleně: podoba částečně diferencovaného vzdělávání na druhém stupni ZŠ optikou učitelů
}

\author{
Jana Navrátilová \\ Masarykova univerzita, Filozofická fakulta, Ústav pedagogických věd \\ Redakci zasláno 2.10. 2019 / upravená verze obdržena 23. 9. 2020 / \\ / k uveřejnění přijato 23. 9. 2020
}

\begin{abstract}
Abstrakt: Studie analyzuje současnou situaci částečné diferenciace (rozdělování žáků v určitých předmětech, na část vyučování) na druhém stupni základních škol v Brně. Teoretická část je věnovaná problematice diferencovaného vzdělávání v ČR. Dále představuje mechanismus částečné diferenciace, na niž je nazíráno jako na jemnější formu dělení žáků. Studie je koncipovaná jako kvalitativní výzkumné šetření. Data byla získána prostřednictvím rozhovorů s vedením škol $(n=4)$ a individuálních rozhovorů s učiteli $(\mathrm{n}=6)$, kteří mají př́mou zkušenost s výukou $\mathrm{v}$ diferencovaných skupinách. $Z$ výsledků vyplývá, že žáci jsou při částečné diferenciaci rozdělováni do dvou homogenizovaných skupin podle předem stanoveného kritéria - výkonu. Učitelé využívají částečně odděleného vzdělávání $\mathrm{k}$ tomu, aby mohli snáze diferencovat výuku, a to podle obsahu učební látky, tempa učení, ale také podle očekávaných schopností žáků v jednotlivých skupinách. Data dále ukázala, že se učitelé i vedení škol v určitých tématech týkajících se realizace částečně diferencované výuky na jejich školách rozcházejí.
\end{abstract}

Klíčová slova: trvalá diferenciace, částečná diferenciace, diferencovaná výuka, rovné vzdělávací př́ležitosti, individuální rozhovory, druhý stupeň základní školy

Český vzdělávací systém je pověstný tím, že hojně a často využívá rozdělování žáků do různých proudů vzdělávání (MŠMT, 2001; Straková \& Simonová, 2015; Obrovská, 2016). Děje se tak ve snaze uspokojit rozmanité vzdělávací potřeby různých skupin žáků a jejich rodičů (STEM/MARK, 2009), což lze považovat za žádoucí. Kriticky nahlíženo je však na to, že jsou žáci rozdělováni podle kognitivních schopností nebo podle socioekonomického statusu do trvalých vzdělávacích drah/větví.

Důsledky, které pramení z diferencovaného vzdělávacího systému, se výrazně promítají také do oblasti vzdělávací politiky. $\mathrm{V}$ této rovině lze sledovat řadu opatření, která se snaží vnější, respektive trvalou diferenciaci ${ }^{1}$ - přede-

1 V celém textu je vnější diferenciace označena jako diferenciace trvalá a vnitřní diferenciace jako částečná. Domnívám se, že zvolená adjektiva lépe vystihují rozdíl mezi těmito dvěma 
vším v hlavním vzdělávacím proudu - redukovat, a posilovat tak praxi společného neboli inkluzivního vzdělávání (viz doporučení OECD, 2011; MŠMT, 2013). Zavést tuto myšlenku do praxe ovšem není jednoduché. Výzkumy totiž ukazují, že názory na trvalou diferenciaci žáků jsou u pedagogické i laické veřejnosti nekonzistentní (např. Greger et al., 2009; Mouralová, 2013). Často diskutovaným typem vnější diferenciace jsou víceletá gymnázia. Zejména učitelé nejčastěji namítají, že odchodem žáků na tento typ škol trpí především základní školy, které se stávají školami tzv. zbytkovými, resp. tř́ídami „přebraných“ žáků. Na druhou stranu učitelé neopomínají zmínit benefity gymnaziálního vzdělávání, např. stimulující kolektiv.

Jistý kompromis mezi trvalým rozdělováním žáků do různých škol či tř́́d a společným vzděláváním může nabízet vnitřní diferenciace, tzn. diferenciace částečná, při níž dochází k rozdělování třídy do skupin pouze na část vyučování (Gamoran, 1992; Vališová \& Kasíková, 2007; Willkinson, Penney, \& Allin, 2016). V českém prostředí se ovšem tomuto fenoménu výzkumné studie př́íliš nevěnují. Ve snaze zaplnit toto bílé místo se předložená studie zabývá částečnou diferenciací na druhém stupni základních škol. Cílem je popsat situaci částečné diferenciace na brněnských školách z perspektivy učitelů, kteří mají vlastní výukovou zkušenost s tímto typem dělení žáků. Perspektivu učitelů považujeme za významnou pro to, že učitelé jsou v podstatě hlavními aktéry realizace vzdělávací politiky. Jsou těmi, kteří jí dávají konkrétní podobu (Mouralová, 2013, s. 13). Vzhledem k tomu, že se požadavek na proměnu našeho selektivního vzdělávacího systému opakovaně objevuje $\mathrm{v}$ různých strategických dokumentech (např. MŠMT 2001, 2013), je více než žádoucí znát výpovědi učitelů, kteří vydaná opatření mají zavádět do praxe. Jestliže se školy rozhodnou realizovat určitý typ diferenciace, jsou to často právě učitelé, kteři žáky rozdělují podle vlastního rozřazovacího klíče. Jsou přirozeně těmi, kteří připravují a realizují diferencovanou výuku. Jsou ale také těmi, kteří představují konkrétní podobu diferencované výuky rodičům. Jejich zkušenosti s diferencovanou výukou mohou např. pomoci odhalit potenciální úskalí, kvưli nimž se nemusí dařit naplňovat hlavní myšlenky inkluzivního vzdělávání, a proto $\mathrm{v}$ této studii zjišt’ujeme právě jejich perspektivu.

typy dělení žáků (už jen např. z toho pohledu, že i vnější diferenciace může probíhat uvnitř školy). 


\section{Diferenciace v základním vzdělávání v ČR}

Vzdělávací systémy jednotlivých zemí se v mnoha ohledech liší. Odlišují se např́íklad v délce trvání povinné školní docházky, ve věku nástupu do první třídy, ale také v tom, do jaké míry jsou diferencované a jaké konkrétní mechanismy diferenciace nabízejí. Rozdělování žáků do různých vzdělávacích proudů probíhá téměř v každém vzdělávacím systému a může nabývat různých podob. $V$ tom českém je uplatňována zejména trvalá diferenciace, tj. cílené a trvalé rozdělování žáků podle určitých kritérií do různých vzdělávacích proudů, větví s různými nároky a zaměřením (srov. Lucas, 2001; Greger \& Holubová, 2010; Veselý \& Matějů, 2010). Trvalá diferenciace probíhá na úrovni škol ${ }^{2}$ (např. víceletá gymnázia) nebo uvnitř školy - na úrovni jednotlivých trríd ${ }^{3}$ (např. třídy s rozšířenou výukou nějakého předmětu). Žáci jsou přitom nejčastěji rozdělováni podle kognitivních schopnostít ${ }^{4}$ (Salchegger, 2016, s. 405; Guill, Lüdtke, \& Köller, 2017, s. 44) nebo podle socioekonomického statusu (Straková, 2010).

V českém vzdělávacím systému je trvalá diferenciace uplatňována poměrně hojně a brzy. K první selekci žáků dochází již při vstupu do povinného vzdělávání. Další vlna rozdělování žáků nastupuje po ukončení primárního stupně vzdělávání (ISCED 1), kdy část žáků mění svoji současnou základní školu a odchází např. na víceletá gymnázia. Vedle těchto formálních cest diferenciace může k rozdělování žáků docházet „pod střechou školy“, a to v podstatě kdykoli během plnění povinné školní docházky. Žáci bývají rozdělováni do různých výběrových tříd, do studijních skupin, oddělení (Školský zákon, $2005, \S 16$, odst. $9, \S 17$, odst. 2). Nabídka vzdělávacích programů výběrových tříd ovšem není nijak monitorována a diferenciace postupuje zcela živelným způsobem (Straková \& Simonová, 2010, s. 592). Výzkumy přitom opakovaně potvrzují, že brzká diferenciace posiluje vliv rodinného zázemí na volbu vzdělávací dráhy (např. Echols, McPherson, \& Willms, 1990; Matějů \& Straková, 2003; Greger \& Holubová, 2010; Straková \& Simonová, 2010). Čím dříve k ní dochází, tím spíše se ve výběru vzdělávací cesty angažují rodiče - zejména rodiče s vyšším socioekonomickým statusem (Matějů \& Straková, 2003; Söderström \& Uusitalo, 2010; Butler et al., 2013; Kaščák \& Betáková, 2014). Jiný pohled na vztah volby školy a socioekonomického

Tzv. tracking.

Tzv. streaming či setting.

Žáci se také mohou rozdělovat na základě svých zájmů, motivů atp. Příkladem tohoto typu diferenciace jsou volitelné předměty (Kasíková \& Straková, et al., 2011, s. 231). 
statusu rodin nabízejí Bittnerová, Doubek a Levínská (2011). Uvádějí, že o volbě základní školy strategicky nepřemýšlejí jen rodiče $s$ vyšším socioekonomickým statusem, ale také rodiče dětí pocházejících $\mathrm{z}$ vyloučených lokalit (zejména romští rodiče), u nichž lze předpokládat nižší socioekonomický status. Tito rodiče pro své děti volí cíleně školy praktické, respektive segregované školy nacházející se v blízkosti vyloučených lokalit. Vstupem do běžných základních škol totiž mohou romské děti zažívat pocit disrespektu, stigmatizace, odmítnutí či ponížení (Bittnerová, Doubek, \& Levínská, 2011, s. 250). V segregovaných školách se jim naopak dostává pochopení, a hlavně přijetí ze strany učitele i spolužáků, což pro ně může být leckdy důležitější než samotné vzdělání.

Vysoká selektivita patří k nejčastěji zmiňovaným úskalím našeho vzdělávacího systému. Kontroverzně vnímaná je právě diferenciace žáků v povinném vzdělávání, zejména diferenciace na nižší sekundární úrovni. Předmětem diskusí se stávají odchody žáků do výběrových a nevýběrových proudů (např. Straková \& Greger, 2013). Vzhledem k tomu, že jsou žáci do výběrových škol a tříd přijímáni zpravidla na základě přijímacích zkoušek (srov. Hornby \& Witte, 2014; Šojdrová et al., 2014), jsou ve výhodě žáci, kteří se narodili do podnětného rodinného prostředí. Rodiče jsou totiž ochotni a schopni vynaložit více energie $\mathrm{k}$ tomu, aby bylo jejich dítě v přijímacích zkouškách úspěšné. V nevýhodě jsou naopak žáci, kteří se do takových rodin nenarodili, ačkoli by mohli být ve studiu na výběrových školách úspěšní. Data z českého prostředí stejně jako nálezy zahraniční provenience dále ukazují, že trvalá diferenciace nevede k celkově lepším výsledkům všech žáků, nýbrž spíše umocňuje rozdíly ve výsledcích žáků z výběrových a nevýběrových větví (např. Ireson, Clark, \& Hallam, 2002; Katrňák, Simonová, \& Fónadová, 2013; Greger et al., 2017). Výběrové větve tedy snáze přispívají k reprodukci vzdělanostních nerovností - namísto toho, aby fungovaly jako nástroj vzdělanostní mobility.

\section{1 Částečná diferenciace jako jemnější forma dělení žákủ}

Vzhledem $\mathrm{k}$ úskalím pramenícím $\mathrm{z}$ diferencovaného vzdělávacího systému se tvůrci vzdělávacích politik snaží o jeho reorganizaci. Cílem je vnější diferenciaci (především v povinném vzdělávání) oslabit a směřovat ke společnému vzdělávání s dostatečnou diferenciací uvnitř heterogenních tříd (MŠMT, 2013). Snahou je, aby se žáci primárně vzdělávali pospolu a k oddělenému vzdělávání docházelo jen částečně. 
Částečnou diferenciací (tzv. ability grouping) se v této studii rozumí rozdělování žáků stejné třídy nebo ročníku pouze v některých předmětech, tedy na menší část školního dne. $V$ ostatních předmětech se vzdělávají všichni dohromady (Greger, 2004, s. 366; Wilkinson, Penney, \& Allin, 2015, s. 3). Tato částečná diferenciace může nabývat různé intenzity. Nejintenzivnější formou je dělení žáků na skupiny/trř́dy napříč ročníkem, např. dle pokročilosti v cizím jazyce. Méně intenzivní formou je dělení žáků stejné třídy do samostatných skupin/mikro-tříd, např. dělení žáků v hlavních předmětech na výkonnostní skupiny. Variantou může být i oddělené vzdělávání žáků jedné tř́ídy $\mathrm{v}$ určitém předmětu, avšak pouze $\mathrm{v}$ některých hodinách $-\mathrm{v}$ jiných hodinách se v daném předmětu vzdělávají společně (Navrátilová, 2019). Nejslabší formou pak je dělení žáků $v$ jakémkoli předmětu v podmínkách heterogenní třídy, např. dělení žáků do skupinek dle čtenářských dovedností (Tieso, 2003, s. 31; Vališová \& Kasíková, 2007, s. 157).

Společné je pro všechny typy částečné diferenciace to, že jsou žáci součástí heterogenního kolektivu a odděleně se vzdělávají jen v některých předmětech. Většinu školního dne tráví všichni pospolu. Toto časové hledisko částečnou diferenciaci odlišuje od diferenciace vnější, trvalé. Lze ji tedy považovat za jemnější formu dělení žáků (Hornby \& Witte, 2014). Její přidaná hodnota spočívá $\mathrm{v}$ tom, že by měla do jisté míry kompenzovat některá úskalí rigidního rozdělování žáků do různých vzdělávacích proudů. Určení homogenity žáků pouze v některých předmětech je přeci jen citlivější než určení celkové homogenity pro všechny předměty. Jestliže se žáci rozdělují podle schopností či výkonu, rozdíly ve výsledcích by neměly být tolik markantní, protože se vzdělávají odděleně jen $v$ menšině předmětů, případně pouze v některých hodinách daných předmětů. Pokud se během školního roku změní výkon žáka, nemělo by být problematické přejít do skupiny odpovídající úrovně, protože se do skupin rozdělují žáci jedné třídy. Davies, Hallam a Ireson (2010) ve své studii potvrzují, že v př́ípadě diferenciace žáků ve třídě může učitel dennodenně monitorovat a vyhodnocovat aktuální úroveň schopností žáků. Tato forma dělení žáků je tedy z hlediska flexibility nejúčinnější. Při trvalém rozdělování žáků do určitých drah je přechod komplikovanější. 0 to komplikovanější je, pokud má žák přejít ze skupiny méně výkonných žáků do skupiny výkonnějších (Vališová \& Kasíková, 2007, s. 157). Některé zahraniční výzkumy dokonce uvádějí, že žáci bývají mnohdy do skupin rozřazeni špatně, tj. nacházejí se ve skupině, která neodpovídá jejich aktuální úrovni. Výzkumy dále zjistily, že žáci skupiny nemění, ani když dojde ke změně v jejich výkonu (Ireson, Clark, \& Hallam, 2002). Flexibilní podoba částečné diferenciace by těmto kritickým momentům mohla předejít. 


\subsection{Diferencovaná výuka jako součást homogenního seskupování žáků}

Vnitřně diferencované základní vzdělávání by mělo reagovat na různorodé potřeby různých skupin žáků (Tannenbergerová, 2016, s. 18). Toto východisko však může platit pouze za předpokladu, že vedle mechanického rozdělování žáků do skupin (byt' jen na určité předměty) bude také diferencovaná samotná výuka. Částečná diferenciace totiž sama o sobě nezaručuje, že bude výuka přizpůsobena individuálním potřebám žáků. Jedná se pouze o způsob rozdělování žáků podle určitého klíče. Diferencovaná výuka tedy předpokládá změnu charakteru vyučování, kdy je výuka plánovaná a realizovaná s ohledem na možnosti, schopnosti, ale také např. zájmy nebo učební styl žáků (Loveless, 1998; Tieso, 2003; Kutnick et al., 2005; Prast et al., 2018). Výuka může být diferencovaná co do obsahu (content), didaktického zprostředkování učiva (process), ale také např. způsobem testování žáků (product) (Tomlinson, 2014, s. 72-73). Obsahem se přitom myslí učivo, které je žákům prezentováno ve výuce, ale také jeho strukturace. Proces označuje různé aktivity, metody a techniky které pomáhají žákům porozumět učební látce a procvičit si ji. Učitelé mohou také volit odlišné způsoby testování žáků a volit různé metody a kritéria hodnocení (Smale-Jacobse et al., 2019). Výuku lze také diferencovat $\mathrm{z}$ hlediska učebního tempa, tzn. učitelé mohou určitým žákům nabídnout více času k učení, anebo naopak určitým žákům zprostředkovat učivo $v$ rychlejším tempu či dokonce v dřívějším věku (Pressey, 1949). Tzv. akcelerace (acceleration) učiva spolu s jeho obohacováním (enrichment) patří k základním postupům ve vzdělávání nadaných žáků. Lze je však použít u všech žáků, nikoli pouze u žáků nadaných. Diferencovaná nemusí být pouze výuka, ale také (před)příprava na výuku (pre-teaching). Žáci mohou dostávat různě zaměřené domácí úkoly nebo si mohou nastudovat určitou učební látku predem (Smets \& Struyven, 2018).

Převést myšlenku diferencované výuky do školní praxe je poměrně ambiciózní čin. Lze dokonce tvrdit, že není v moci ani těch nejschopnějších učitelů přizpůsobovat výuku každému žákovi ve třídě (Northey, 2005, s. 11; Fuchs \& Vaughn, 2012, s. 198). Vzhledem k tomu, že vytvářet učební možnosti pro každého jednoho žáka ve třídě je obtížné, učitelé mohou využívat různého seskupování žáků dle jednotného kritéria. Pravděpodobně bude snazší připravovat výuku pro skupinu žáků obdobných schopností nebo např. zájmů než se věnovat každému žákovi zvlášt'. Navíc už jen tím, že učitelé žáky rozdělí do menších skupin, získají čas a prostor věnovat se jednotlivcům. Lze tedy uvést, že částečná diferenciace může fungovat jako platforma pro implementaci diferenciačních strategií. 


\section{Metodologie}

Předkládaná studie prezentuje dílčí výsledky výzkumného šetření, jehož cílem je získat empirické poznání současné situace částečné diferenciace na základních školách. Částečná diferenciace je chápána jako organizační uspořádání seskupující žáky jedné třídy do homogenních skupin podle určitých kritérií (Hornby \& Witte, 2014).

Výzkumné šetření se opírá o kvalitativní získaná data sesbíraná ve školním roce 2017-2018 a částečně také ve školním roce 2018-2019. Cílem bylo porozumět samotnému mechanismu částečné diferenciace v prostředí druhého stupně základních škol. Otázka, na kterou studie hledá odpověd, zní: proč školy přistoupily na myšlenku diferencovaného vzdělávání, tedy z jakého důvodu částečnou diferenciaci využívají. Důvodů pro její realizaci může být několik (např. aktuální grantová schémata, která umožňují diferenciaci žáků). $\mathrm{V}$ tomto textu ovšem nejsou přímo uváděny záměry vedení škol. Percepce důvodů pro rozdělování žáků je prezentována primárně z pozice samotných učitelů, kteří v diferencovaných skupinách vyučují. Nutno poznamenat, že část učitelů, kteří v diferencovaných skupinách učí, zastávají současně pozici ředitelů/zástupců. Získaná data tak v určité rovině zachycují drobné nuance ve výpovědích učitelů, kteří působí ve vedení, a učitelů, kteří tuto pozici nezastávají. Dále jsem zjištovala, jakým způsobem je diferenciace zajištěna organizačně. Studie zachycuje, $v$ jakých předmětech se žáci rozdělují, podle jakých charakteristik jsou rozřazeni, jakým způsobem učitelé tyto charakteristiky zjištují a také zda je rozdělení žáků flexibilní. V neposlední řadě pak studie ukazuje, jakým způsobem si učitelé připravují výuku v homogenních skupinách. Šlo o to zjistit, zda jsou žáci rozděleni do skupin samoúčelně a výuka není nijak diferencovaná, anebo zda jsou žáci rozděleni cíleně a učitelé volí různé diferenciační strategie s ohledem na kritéria rozdělování žáků.

\subsection{Výzkumné otázky}

V návaznosti na zaměření této studie je jejím cílem zodpovědět následující výzkumné otázky:

1) Jak učitelé hovoří o důvodech pro zavedení částečné diferenciace?

2) Jak učitelé popisují mechanismus rozdělování žáků?

3) Jak učitelé vypovídají o přípravě výuky pro homogenní skupiny?

4) Jak se do výpovědi o diferencované výuce promítá perspektiva učitelů, kteří současně zastávají vedoucí pozici? 


\subsection{Konstrukce vzorku}

Výzkumné šetření, z něhož vychází tento text, bylo realizováno na druhém stupni brněnských základních škol. Kritérium pro volbu škol bylo v podstatě jediné - vybrat takové školy, které rozdělují žáky šesté tř́idy v určitých předmětech do skupin, avšak většinu předmětů zároveň žáci absolvují dohromady. Šestý ročník byl zvolen záměrně. Jedná se o první ročník na druhém stupni, ve kterém jsou žáci jedné třídy děleni do skupin. Jedná se navíc o ročník, který s sebou často nese proměnu ve složení třídy jakožto následek odchodu žáků na jiné typy škol. Př́kladem mohou být víceletá gymnázia, která základním školám opakovaně konkurují a zbavují je zpravidla nadaných žáků (srov. Greger \& Holubová, 2010; Walterová et al., 2011). Obzvláště silnou konkurenci lze očekávat mezi školami situovanými ve velkých městech, což v našem př́padě Brno nepochybně je. Zaměřila jsem se tedy na městské základní školy, u nichž lze předpokládat, že realizací částečně diferencované výuky do jisté míry konkurují (nejen) víceletým gymnáziím. Částečně diferencované vzdělávání totiž nabízí způsob, jak uspokojit vzdělávací potřeby různých skupin žáků, avšak tak, aby nedošlo k jejich vyčleňování mimo hlavní vzdělávací proud.

Postup konstrukce vzorku byl následující. Na portálu Atlas školství jsem nej-

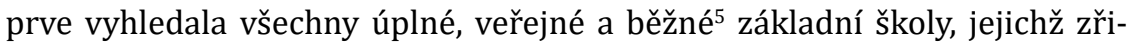
zovatelem je statutární město Brno. Celkový počet škol činil 62 . S vedením těchto škol proběhl telefonický rozhovor, jehož cílem bylo zjistit, zda žáky šesté trrídy v některých předmětech rozdělují do skupin/oddělení. Z celkového počtu 62 oslovených škol odpovídalo zvolenému kritériu pouze pět škol. Vybraných pět škol jsem požádala o hlubší spolupráci. Vedení mi předalo kontakty na učitele, kteří vyučují v diferencovaných skupinách. S těmito vyučujícími proběhlo osobní setkání, jehož cílem bylo získat detailní informace o způsobech realizace částečné diferenciace.

Již z telefonních rozhovorů s členy vedení jednotlivých škol vyplynulo, že všech pět škol volí částečnou diferenciaci pro hlavní předměty, čili pro český jazyk a matematiku. ${ }^{6}$ Každý předmět vyučuje jiný vyučující. Navazující indivi-

Za běžnou základní školu je v tomto textu považovaná taková škola, která sama sebe ani svoji vzdělávací koncepci neoznačuje za alternativní ani není určena pro žáky vyjmenované v $§ 16$, odstavec 9, školského zákona.

6 Základní školy volí diferenciaci žáků také pro cizí jazyky. Diferenciace vypadá standardně tak, že se žáci všech šestých tříd na cizí jazyk přeskupují do tříd homogenních. Rozděleni jsou dle pokročilosti v jazyce do paralelních větví. Diferenciace probíhá ve všech hodinách cizích 
duální rozhovory proběhly na každé škole s oběma vyučujícími daných předmětů zvlášt'. Osobního setkání se zúčastnilo celkem 10 vyučujících, z nichž čtyři současně působili ve vedení školy.

\section{Charakteristika vybraných základních škol z hlediska částečné diferenciace}

Všech pět základních škol uplatňuje $\mathrm{v}$ šestém ročníku mechanismus částečné diferenciace. Organizační zajištění diferenciace je na vybraných školách v podstatě identické. Žáci jsou vždy na začátku školního roku rozděleni v hlavních předmětech (český jazyk, matematika) do dvou skupin. $V$ tomto seskupení se vzdělávají pouze jednou týdně, a to paralelně. Jedná se o částečnou diferenciaci, což znamená, že žáci jsou rozděleni jen ve dvou předmětech a jen v některých hodinách. Např́klad v pondělí se během první vyučovací hodiny jedna skupina učí český jazyk a druhá skupina se učí matematiku. Během další vyučovací hodiny nebo v kterýkoli jiný den se skupiny vymění. V ostatních vyučovacích hodinách $\mathrm{v}$ daných předmětech (tři vyučovací hodiny v každém předmětu) se vzdělávají všichni dohromady v jedné tř́ídě. Školy tedy využívají heterogenního a homogenního uspořádání, přičemž heterogenní třídy jsou dominantním uspořádáním. Výuka v homogenních skupinách probíhá v samostatných třídách. Český jazyk vyučuje v obou skupinách stejný vyučující, obdobně je tomu v matematice.

Co se týče složení žáků v šestých ročnících vybraných základních škol: tyto třídy navštěvují spolu s ostatními žáky také žáci se speciálními vzdělávacími potřebami (dále jen SVP), nejčastěji se jedná o žáky se specifickými poruchami učení. Tito žáci se zpravidla vzdělávají podle individuálního vzdělávacího plánu, př́ípadně je pro ně vytvořen plán pedagogické podpory. Nadaní žáci se na vybraných školách vzdělávají, nicméně v jiných ročnících. Šesté ročníky během sběru dat nadaní žáci nenavštěvovali. Ve třech šestých ročnících (z celkového počtu pěti škol) byl prítomen také asistent pedagoga.

\subsection{Metody sběru dat}

Sběr dat, z nichž tato studie vychází, sestával ze dvou kroků. Prvním krokem bylo vyhledání základních škol, které na druhém stupni žáky rozdělují

jazyků a v každé třídě působí jiný učitel. Vzhledem $\mathrm{k}$ tomu, že se tato diferenciace napříč ročníkem od diferenciace $\mathrm{v}$ hlavních předmětech $\mathrm{v}$ mnohém odlišuje, nebyla předmětem zkoumání. Další důvod pro její vyřazení je, že se na některých školách proměňuje organizačně (např. v některém školním roce se dělí žáci jedné třídy do oddělení, v jiném školním roce se rozdělují žáci napříč ročníky). 
v určitých předmětech do skupin. Nejjednodušší cestou, jak tuto informaci získat, bylo základní školy telefonicky kontaktovat a požádat vedení o odpověd'. Realizovala jsem telefonní rozhovor (Miovský, 2006, s. 156) s celkem 62 zástupci ředitelů, popřípadě přímo s řediteli daných škol. Cílem bylo získat od všech respondentů poměrně krátké, tematicky specifické informace - zda uplatňují částečnou diferenciaci, a pokud ano, tak v jakých předmětech a jakým způsobem žáky dělí. Telefonní rozhovor měl typicky strukturovanou formu (McKay, 2006; Zacharias, 2012). To znamená, že všichni dotazovaní odpovídali na stejné otázky formulované ve stejném pořadí (Cohen, Manion, \& Morrison, 2007, s. 353; Patton, 2002, s. 344). Za účelem zajištění standardizovaných podmínek jsem měla připraveno fixní schéma s přesným zněním otázek. Rozhovory trvaly v průměru 10 minut. Data získaná touto cestou lze označit za vstupní tvrdá data, na jejichž základě jsem požádala o navazující spolupráci pouze ty základní školy, které diferenciaci využívají. V návaznosti na výsledky z telefonního rozhovoru jsem navázala spolupráci s celkem pěti základními školami. Od vedení jsem získala kontakty na učitele, kteří v diferencovaných skupinách vyučují.

V druhém kroku sběru dat jsem se domluvila s konkrétními vyučujícími na osobním setkání, jehož cílem bylo zjistit, jak o diferenciaci hovoří samotní učitelé, kteří v diferencovaných skupinách reálně vyučují. Data jsem získala prostřednictvím polostrukturovaného rozhovoru, který mi umožnil získat hlubší a komplexnější informace o zkušenostech, názorech, přesvědčeních, ale také např. o motivech participantů (Gill et al., 2008). Struktura rozhovoru byla volnější, nicméně jisté schéma v podobě předpřipravených otázek (interview schedule) figurovalo i v tomto typu rozhovoru. Kvalitativně orientovaná studie tak zprostředkovává subjektivní názory a postoje učitelů s vlastní výukovou zkušeností s vnitřně diferencovanou výukou.

Polostrukturované rozhovory trvaly v průměru 45 minut a probíhaly v kabinetech vyučujících. $V$ době jejich pořizování byl v kabinetě vždy přítomen pouze vyučující a výzkumnice. Respondenti byli před začátkem rozhovoru seznámeni s cíli výzkumu a jeho průběhem, přičemž téma výzkumu znali zástupci ředitele $\mathrm{z}$ předchozí telefonické komunikace. Před samotným začátkem vyslovili respondenti souhlas s nahráváním, přičemž byli ubezpečeni, že s pořízenými daty bude zacházeno jako s anonymními. Všechna jména respondentů uveřejněná v tomto prŕspěvku jsou nahrazena pseudonymy. ${ }^{7}$

7 Učitelé působící na jedné škole mají pseudonym začínající stejným písmenem. 


\subsection{Analýza dat}

Data získaná z telefonních strukturovaných rozhovorů referovala o tom, které školy žáky na druhém stupni $v$ určitých předmětech dělí. Abych získala přehled takových škol, vytvořila jsem si nejprve seznam všech základních škol (tzv. checklist format dle McDonough \& McDonough, 1997). Podle odpovědí od vedení jednotlivých škol jsem si zaznamenala pouze ty, které odpovídaly zvolenému kritériu (tzv. tick-the-box coding procedure dle Burns, 2010, s. 75). Podrobnější informace získané z telefonních rozhovorů s vedením pěti vybraných škol, které se týkaly způsobu diferenciace žáků, jsem zaznamenávala formou poznámek. $V$ analýze těchto dat bylo užito deskripce jakožto první úrovně tř́ídění.

Data získaná z polostrukturovaných rozhovorů jsem podrobila doslovné transkripci. Přepsané rozhovory jsem následně analyzovala běžnými kódovacími technikami, které vznikly v rámci designu zakotvené teorie (Strauss \& Corbinová, 1999), a sice otevřeným kódováním a kategorizováním. Postup analýzy byl následující. Nejprve jsem vyhledala tzv. významové jednotky (Miovský, 2006), tj. úseky textu, které se vztahovaly k výzkumným otázkám. Každou významovou jednotku jsem pojmenovala tak, aby co nejvýstižněji reprezentovala daný výsek textu. Vzniklé kódy/výseky jsem abstrahovala a seskupila do větších celků neboli kategorií. Součástí kategorizování dat se stalo také jejich editorování (Miles \& Huberman, 1994). To znamená, že vzniklé významové jednotky jsem doplňovala o data získaná z poznámek z telefonních rozhovorů.

\section{Výsledky výzkumu}

\subsection{Kontext zavedení částečné diferenciace}

V odpovědi na otázku, proč se základní školy rozhodly pro diferenciaci žáků v šestých ročnících, se učitelé jednoznačně shodli: „Dělíme je, pokud máme ve třídách hodně dětí, kolem těch pětadvaceti a výš," uvedla učitelka Bětka. Základní školy se $\mathrm{k}$ diferenciaci uchylovaly $\mathrm{v}$ případě většího počtu žáků ve třídách, kterého dosáhly sloučením paralelních tříd do jedné: „Museli jsme ty šestky sloučit, protože hodně žáků odešlo na gymnázia," dodala učitelka Dita. Ukazuje se, že hranice přechodu žáků z primární na nižší sekundární úroveň dostává učitele do poměrně paradoxní situace. Vzhledem k tomu, že řada žáků odchází po absolvování prvního stupně na víceletá gymnázia, 
jsou školy nuceny úbytek žáků jistým způsobem kompenzovat. Jako řešení se nabízí sloučit prořídlé šesté třídy do jedné, která se najednou stává třídou početnou. Učitelka Ester celou situaci shrnula a dodala: „V těch šestkách spoustu žáků odejde, zbyde minimum, a ti se různě propojí, přijdou žáci z jiných škol, aby utvořili celou třídu, a ten kolektiv je pak úplně jiný, nový." Pokud sloučení tříd nestačí, počty žáků jsou navýšeny žáky nově příchozími. Jedná se o výsledek jakéhosi náboru žákủ z jiných škol. Učitelka v závěru výpovědi referuje o dopadech mechanického přeskupování žáků na proměnu složení tříd.

$\mathrm{Z}$ výpovědí je na první pohled patrné, že se školy $\mathrm{k}$ diferenciaci uchylují v př́ípadě početných tříd. Učitelé přitom dodávají, že početné třídy samy o sobě nejsou jediným důvodem pro zavedení výuky v dělených skupinách. Výpovědi učitelů odkazují k značné diverzitě žáků, která je podle nich způsobena tzv. rekonstrukcí, zejména šestých tříd. Učitelka Dana například uvedla: „(...) v té šestce máme ted'ka navíc i několik žákủ, kteří k nám přišli z malotř́ídky, ale taky přišlo pár žáků z úplně jiných škol, takže to máme ted'ka pestrý." Žákovskou diverzitu ve výpovědi zmiňovala také učitelka Dita: „Jak je jich tam hodně, tak jsou mezi nima prostě rozdíly - a tím, že je rozdělíme, tak se můžeme věnovat každé té skupině zvlášt'." Výpovědi učitelů naznačují, že proměna v sociálním složení tř́́dy přivedla školy k myšlence žáky určitým způsobem rozdělit. Učitelé vysvětlují, že je nově vzniklý kolektiv značně různorodý. Ve snaze uspokojit různé (vzdělávací) potřeby žáků se školy rozhodly žáky na hlavní předměty dělit do skupin. Pokud učitelé vyučují v menších skupinách, mohou přirozeně lépe individualizovat výuku. Učitelé ovšem doplňují, že je nezbytné žáky do skupin dělit cíleně. Možnost vyučovat ve třídě složené z menšího počtu žáků samozřejmě kvitují, nicméně podotýkají, že je potřeba žáky do skupin rozdělit podle určitého kritéria. Nabízí se otázka, jaké charakteristiky na straně žáků učitelé považují za rozhodující v procesu dělení žáků. Učitelé se unisono shodli na tom, podle jakých charakteristik žáky rozdělují. Učitelka Claudie odpověděla: „Žáky rozdělujeme v té češtině a matematice na dvě skupiny. Jedna je ta lepší a druhá je ta slabší, pomalejší," přičemž ,jjou rozděleni podle výkonu," jak doplňuje učitel Boris. Učitelé tedy volí kvantitativní diferenciaci, nebot' žáky v hlavních předmětech sdružují do skupin podle výkonu - skupina výkonnějších a méně výkonných. Obdobně se vyjadřuje učitelka Claudie: „Dělíme je podle výkonosti na dvě skupiny, na tu jako by slabší [řečeno v uvozovkách] a silnější nebo jak to mám říct." Zatímco samotné kritérium výkonnosti vyslovili dotazovaní učitelé bez okolků, 
jednotlivým skupinám přiřazovali různé labely se zřejmou obezřetností. Vedle označení slabší a silnější figurovaly nálepky horší a lepší (např. učitelka Bětka), pomalejší a rychlejší (např. učitelka Dana), leckdy také ti nadějní a ten zbytek (učitelka Anna). Prezentované labely prozrazují, že učitelé rozdělují žáky na dvě výkonnostně kontrastní skupiny, přičemž nejsilněji evokuje výkonnostní rozdílnost vyjádření učitelky Anny. Na rozdíly mezi žáky poukazovali učitelé v průběhu rozhovorů opakovaně. Jak je ovšem možné, že jsou mezi žáky tak markantní rozdíly, když ve výpovědích učitelů opakovaně zaznívaly výroky typu: „Většina těch nadaných odešla na gymply, zůstal tu ten zbytek, který na gympl nemá." (učitelka Anna). Citace reflektuje proměnu ve složení třídy, ke které došlo v důsledku odchodů schopnějších žáků na víceletá gymnázia. $V$ šestých tř́́dách podle učitelky Anny zůstali žáci méně schopní, kteří svými schopnostmi na gymnázia nedosahují. Z výpovědí učitelů je však zřejmé, že si vzájemně protiřečí. Na jednu stranu uvádějí, že jsou mezi žáky šesté tř́ídy značné výkonnostní rozdíly - což je podle učitelů důvod k tomu, proč žáky rozdělit do skupin. Na straně druhé přiznávají, že jim víceletá gymnázia odvádí schopnější žáky, a ve třídách tak zůstávají žáci méně schopní.

Pozoruhodné je, že žáci jsou ve zkoumaných školách rozdělováni vždy podle stejného kvantitativního kritéria - jejich výkonu. Dělení žáků podle kvalitativního kritéria, např. podle jejich vlastních preferencí, neuplatňovala žádná škola, a to i za předpokladu, že dělící kritérium si volí učitelé sami: „My si ty děcka můžeme rozdělit, jak uznáme za vhodný," uvedla učitelka Anna. To znamená, že vedení škol diferenciaci umožní, avšak rozhodnutí o tom, jakým způsobem budou žáci děleni, stojí na bedrech samotných vyučujících. Učitelé svoje rozhodnutí opírají o rozdílné výkony žáků. Přidělování žáků do homogenních skupin variabilitu $\mathrm{v}$ jejich výkonech do určité míry redukuje. Jiný způsob dělení žáků učitelé nepřipouští. Následně dodávají, že jim jiné kritérium - zejména kvalitativní - neumožňuje organizační zajištění částečné diferenciace (paralelní dělení např́íč předměty).

\subsection{Předpokládané rozdíly ve výkonech žáků}

Pokud třídu tvoří podle učitelů převážně žáci tzv. méně schopní, diferencované skupiny by byly proporčně nevyvážené. Znamenalo by to, že jedna skupina je složena z komorního počtu žáků, druhá skupina je výrazně početnější, složená z většiny žáků třídy. To ale systém rozdělování neumožňuje. „Jsou rozděleni zhruba na půlky, v té lepší skupině jich je myslím třináct 
a v té horší patnáct," uvedla učitelka Ester; učitelé přitom svoje rozhodnutí odůvodňují takto (učitelka Bětka): „Nemůžeme mít v jedné skupině třeba pět žáků a $v$ druhé zbytek, to by pak postrádalo smysl." $\mathrm{Z}$ citace vyplývá, že jsou žáci rozděleni na dvě poloviny záměrně. Při zachování početně nerovnoměrných skupin by se diferenciace stala kontraproduktivní - zejména pro skupinu méně schopných žáků, která by svojí velikostí mohla tvořit samostatnou třídu.

Je k zamyšlení, jakým způsobem učitelé posuzují výkonnost žáků. Učitelé ve svých výpovědích uváděli, že žáky rozdělují na začátku školního roku, což s sebou nese to riziko, že žáky ještě dobře neznají. Neznají ani žáky přicházející z prvního stupně, protože je vyučovali jiní vyučující, ani žáky přicházející z jiných primárních škol. Učitelé tedy využívají různé strategie, jak zjistit výkonnost žáků a zároveň dodržet závazek stejně početných skupin. Učitelka Anna svoji strategii popsala následovně: „Já jsem jim dávala test z matematiky, abych je poznala. A na základě výsledků toho testu jsem je rozdělila, podle procent. První půlka šla do jedné skupiny, druhá půlka pak do druhé." Učitelka zvolila poměrně jednoduché řešení. Jedná se v podstatě o zkoušku relativního výkonu. Nezáleží na tom, zda žák v testu uspěl, lat'ku tvoří dosažený výkon žáků v dané třídě. Výsledkem její metody poznávání je, že na základě výsledků z jednoho testu je žák „zaškatulkován“ do skupiny výkonnějších či méně výkonných žáků. Snaha o poznání žáků prostřednictvím jednorázového testování s sebou zcela jistě nese určitá úskalí, například možnost, že žák bude na určitou dobu zařazen špatně.

Další používanou strategií bylo sondování informací od vyučujících z prvního stupně, kteří žáky vyučovali v pátém ročníku, jejich výkony znají a jsou s to kolegům s diferenciací poradit: „Nechali jsme si to rozdělit od těch učitelů, který je měli v té páté tř́dě, protože jsme je neznali, tak jsme je požádali, kdyby oni si to měli rozdělit, tak, jak by si to rozdělili, takže jsme to převzali od nich," odpověděla učitelka Claudie. Co se týče žáků nově příchozích, učitelé je rozdělovali primárně podle známek na vysvědčení - s tím, že „si všímám, kdo jak reaguje, kdo se, jak zapojuje," jak uvedla učitelka Dita. Citaci posouvá dál učitelka Alena, která uvádí: „Dávali jsme taky trochu na takový ten první dojem, jak se nám kdo zdá." Svoje rozhodnutí tedy učitelé ověřovali ve vyučování. Dodávají ovšem, že se rozhodovali spíše na základě prvních dojmů, než že by se jednalo o výsledek založený na dlouhodobém poznávání. 
Ze získaných dat vyvstává poměrně kontroverzní zjištění. Ukazuje se totiž, že učitelé žáky neznají a diverzitu z hlediska výkonu tak v podstatě jen předpokládají. Skupiny účelově diferencují, tudíž se nesnaží sjednotit znalostní úroveň žáků přecházejících z primárního stupně či úplně jiných škol. Cílem je žáky mechanicky rozdělit podle předem daného kritéria výkonnosti, čímž se rozdíly mezi žáky uměle vytvoří, případně umocní. Učitelé tedy stanovují kritérium výkonnosti ještě dřív, než se s novým kolektivem žáků vůbec seznámí. To, že je kolektiv z hlediska výkonu výrazně heterogenní, je tedy spíše předpoklad či očekávání učitelů. Na druhou stranu lze podotknout, že určitou heterogenitu vykazuje každá tř́da. Nicméně to, že učitelé žáky cíleně rozdělí na dvě kontrastní skupiny, nemusí odpovídat skutečnému složení třídy, ale jejich očekávání o výkonech žáků se může později v důsledku částečné diferenciace naplnit.

Je třeba připomenout, že se žáci rozdělují do skupin ve dvou předmětech. Výuka ve skupinách probíhá paralelně, což znamená, že „jednou týdně mají do protivky matiku a češtinu čili jedna skupina má matiku a ta druhá skupina má češtinu, další hodinu se pak prohodí," jak vysvětlila učitelka Claudie. Jak tedy učitelé rozhodují o dělení žáků v situaci, kdy se v „připisování výkonnosti“ jednotlivým žákům neshodnou? Učitelka Cecílie totiž v rozhovoru explicitně uvedla, že jsou žáci nadaní napříč předměty různě: „Je taky rozdíl $\mathrm{v}$ těch předmětech, je to matika a čeština, takže jsou děcka, který jsou v češtině katastrofální a v matice jim to myslí, a naopak." Učitelé ve zkoumaném vzorku uvedli, že se ve většině případů na rozdělení jednotlivých žáků do skupin shodnou. Jestliže se jejich názory různí, přísluší rozhodovací pravomoc učitelům matematiky a češtináři se musejí podřídit. Výstižně celou situaci reflektovala učitelka Alena: „Tam má hlavní slovo paní učitelka z matematiky, protože $v$ té matice jsou mezi žáky větší rozdíly, já takový rozdíly v češtině nemám, takže jsem se defacto přizpůsobila." Obdobně se vyjadřovala učitelka Dana: „Ustoupila jsem paní učitelce z matematiky s tím, že pokud to nebude fungovat, tak se to v pololetí může zase proměnit." Učitelé matematiky argumentují tím, že je učivo v tomto předmětu náročnější, rozdíly ve výkonech žáků jsou tudíž markantnější než v českém jazyce. Za těchto předpokladů nicméně hrozí riziko, že někteří žáci nebudou rožrazeni správně, tzn. nebudou se nacházet ve skupině, která odpovídá jejich předpokládané výkonnosti. Situaci by mohla vyřešit propustnost mezi skupinami, která by měla být díky částečné diferenciaci žákủ jedné třídy organizačně možná. Vzhledem k tomu, že výuka $v$ diferencovaných skupinách probíhá paralelně, ani propustnost mezi skupinami situaci nevyřeší, žák bude vždy $v$ jednom 
předmětu zařazen špatně. To ovšem neznamená, že by rozdělení žáků bylo fixní. Učitelé v rozhovorech uvedli, že jsou pohyby mezi skupinami během školního roku možné. S blížícím se koncem prvního pololetí o změně skupiny u několika žáků učitelé reálně uvažují: „Přemýšlím ted'ka, jak je mám v té šestce už já nevím, přes tř̌i měsíce, tak už si všímám, že někteří by mohli jít do té lepší skupiny a někteří do té horší, ale musím se samozřejmě domluvit i s paní učitelkou z češtiny," glosovala učitelka Cecílie. Z citace je patrné, že učitelka uvažuje o přechodech žáků oběma směry. $Z$ dat však dále vyplývá, že všichni učitelé takto benevolentní nejsou. Přechody mezi skupinami připouští, avšak pouze jedním směrem, a to směrem dolů: „Nedovedu si moc představit situaci, kdyby žák přešel do té lepší skupiny, tam se jede v daleko rychlejším tempu, probere se daleko víc příkladů, tam se obávám, že by byl problém, že by absolutně nestíhal to tempo," poznamenala učitelka Dita. Obdobně se vyjádřila také učitelka Ester: „Tam se obávám toho přechodu do té lepší skupiny, že by nestíhali." Pokud se tedy v méně výkonné skupině nachází žák, který svým výkonem převyšuje ostatní žáky z dané skupiny, je jeho šance na přechod do výkonnější skupiny mizivá. Důvodem není ani tak obava učitelky z nezvládnutí učební látky, avšak spíše obava z neschopnosti přizpůsobit se učebnímu tempu výkonnější skupiny. Jakmile jsou žáci již jednou rozděleni, učitelé k nim přistupují podle toho, do které skupiny patří. To znamená, že předpokládají určité vlastnosti žáka z příslušné skupiny a vytvářejí si automaticky úsudek o jeho schopnostech. Na základě jejich úsudku potom se žáky jednají - např. předpokládají, že by slabší žáci přechod do výkonnější skupiny nezvládli, proto jim jej ani neumožní. Žáci jsou tak v podstatě odsouzeni k fixnímu přiřazení, a to i za předpokladu, že je pohyb mezi skupinami organizačně nenáročný.

\subsection{Podoba diferencované výuky}

Učitelé uvedli, že žáky rozdělují do výkonnostních skupin, přičemž v každé skupině volí odlišný výukový obsah. Odlišnou podobu diferencované výuky popsala učitelka Claudie následovně: „V té lepší skupině toho probereme víc, tím, že jsou rychlejší, tak si můžu dovolit probrat učivo víc do hloubky, chystám si prostě jiný úkoly, ale u té slabší skupiny, tam jsem ráda, že $\mathrm{s}$ něma zvládnu, co musím." Z citace vyplývá, že si připravuje výuku dvojím způsobem. Výuku ve výkonnější skupině se snaží nastavit tak, aby byla kognitivně náročnější, kdežto výuku v méně výkonné skupině uzpůsobuje základním požadavkům. Jinou zkušenost popsala učitelka Cecílie: „No, ta silnější skupina jede rychleji, stihne toho víc. Kolikrát, i když ten plán na hodinu je stejný, 
tak děláme úplně jiný věci, než jsem si naplánovala, to zvládnem během pár minut a pak děláme nějaký nadstandardní věci nebo zabrousím úplně někam jinam, kam bych si takový otázky u té slabší skupiny netroufla vůbec dávat. Tam spíš procvičujeme to, co jsme probírali v té společné hodině, chci, aby uměli aspoň ty základy.“

Výsledky naznačují, že učitelé diferencují výuku prostřednictvím obsahu učební látky a učebního tempa žáků. $\mathrm{Z}$ hlediska učební látky jde $\mathrm{v}$ zásadě o to, že se učitelé snaží poskytnout základní učivo všem žákům bez ohledu na přiřazení do skupiny. $V$ určité nadstavbě je pak poskytováno žákủm $\mathrm{z}$ výkonnější skupiny. Jedná se o prohlubující učivo, o tzv. enrichment. Vedle toho u skupiny žáků, kteří mají podle učitelů problém se zvládnutím základních požadavků, volí učitelé takové strategie, které mají těmto žákům pomoct si základní učivo osvojit. Učitelé tedy se žáky intenzivněji procvičují a opakují již probranou učební látku. Učebnímu tempu žáků přizpůsobují učební obsah. Akceleraci učiva volí v př́ípadě, když jsou žáci s to zvládnout stejný obsah rychleji. Obohacování učiva a jeho úprava ve smyslu zrychlení se prolínají. S odkazem na výpovědi učitelů jsou žáci z výkonnější skupiny schopni zvládnout výukový obsah rychleji, tudíž se nabízí možnost probrat učivo v širších souvislostech, hlouběji. Akcelerace spolu s tzv. enrichmentem patří k základním přístupům při výuce nadaných žáků. Učitelé nicméně obě metody využívají při práci se žáky, kteří nadaní nejsou, nebot' je považují za funkční.

Data ukazují, že záměrné seskupování žáků do výkonnostních skupin učitele automaticky navádí k tomu, aby výuku určitým způsobem diferencovali. $\mathrm{V}$ každé skupině uplatňují jiné diferenciační strategie a mají pro to vysvětlení. $\mathrm{V}$ rozhovorech se však učitelé vyjadřovali primárně ke skupině výkonnějších žáků. Cílem diferencované výuky u těchto žáků je podle učitelky Anny „aby ti nadanější, aby se rozvíjeli - a v těch běžných spojených hodinách se spíš přizpůsobujem těm slabším, protože tam nemůžeme jet rychlejc“. Diferencovaná výuka by měla této skupině žáků umožnit probrat učivo v rychlejším sledu a zároveň by měla být kognitivně náročnější. Ve standardních hodinách, v nichž se vzdělávají všichni žáci společně, není možné stanoveného cíle dosáhnout. Učitelka své tvrzení zdůvodňuje tak, že je výuka v nediferencované třídě přizpůsobena žákům jinak patřícím do méně výkonné skupiny. Výuka ve skupinách jim tedy určitým způsobem kompenzuje to, co jim nemůže nabídnout výuka při společném vzdělávání. Učitelka Anna svoji výpověd’ doplnila slovy: „Ta lepší skupina, to jsou v podstatě gymnazisti, 
takže i ta výuka by se měla blížit výuce na gymnáziu." Učitel Boris se o této skupině žáků vyjádřil obdobně, nebot' uvedl: „Ta jedna skupina je taková př́ípravka na gympl. Tam pak z té sedmičky se dostane takových devět, deset děcek na gympl.“ Z výpovědí vyplývá, že učitelé mají od těchto žáků vysoká očekávání, čemuž také odpovídá pojetí diferencované výuky. Skupina funguje jako přípravná třída, učitelé se tedy snaží výuku koncipovat tak, aby se zvýšily šance žáků na přijetí na šestiletá gymnázia.

\subsection{Učitelé vs. zástupci: Dva pohledy na vnitřně diferencovanou výuku}

$\mathrm{Z}$ analýzy dat dále vyplynulo, že se názory na problematiku vnitřně diferencovaného vzdělávání $v$ určitých oblastech liší u těch učitelů, kteří jsou současně zástupci ředitelů. $V$ tomto textu jsou prezentovaná dvě ústřední témata, a sice téma konkurence základních škol s víceletými gymnázii a účelu vnitřně diferencované výuky.

Jak učitelé „ř́adoví“, tak učitelé ve vedoucích pozicích během rozhovorů zcela spontánně otevírali téma víceletých gymnázií, která pro jejich školy představují silnou konkurenci - už jen z toho důvodu, že se školy koncentrují ve velkém městě, Brně. Obě skupiny respondentů potvrzovaly již známou skutečnost, že jim na gymnázia odcházejí zpravidla schopnější žáci a v šestých tř́dách „zůstává ten slabší zbytek, který na gympl nemá,“ jak uvedl učitel Boris, přičemž záhy doplnil: „Samozřejmě, v té lepší skupině, tam je pár šikovných, který zvládají srovnatelně těžké učivo s učivem na gymnáziu." Učitel Boris uvedl, že kvůli existenci gymnázií přichází škola o nadanější žáky. Připouští však, že zlomek nadaných žáků v šesté tř́ídě zůstává. Ti se kvůli částečné diferenciaci částečně vzdělávají ve výkonnější skupině a samotná výuka je uzpůsobena jejich schopnostem (viz předcházející kapitola). Nabízí se tedy otázka, zda může vnitřně diferencovaná výuka představovat způsob, jak uspokojit poptávku žáků, případně jejich rodičů, po náročnějším studiu a jak si udržet schopné žáky na druhém stupni. Řadoví učitelé se s vyučujícími ve vedoucí pozici v tomto ohledu názorově rozcházejí. Zatímco učitelé jsou spíše skeptičtí (učitelka Bětka: „Vždycky chtějí jít na gymply, je to volba číslo jedna, i kdybychom se postavili na hlavu, tak ti dobří odejdou."), vedení škol vkládá do částečné diferenciace naději. „Snažíme se je tady udržet zuby nehty, snažíme se tu výuku v lepší skupině pozvednout na úroveň těch gymnaziálních tříd a myslím, že se nám to daří. Máme tu šikovné žáky, kterým ta dělená výuka vyloženě sedí a na gymply se netlačí," uvedla zástupkyně Ester, načež dodala, že díky dělené výuce mohou na druhém stupni zůstávat ti žáci, 
kteří jiné školy zvažují, avšak pevně rozhodnuti nejsou. Učitelé tedy zastávají názor, že ani vnitřně diferencovanou výukou nelze gymnáziím úspěšně konkurovat. Vedení škol naopak připouští, že některým žákům částečná diferenciace spolu s diferenciací výuky vyhovuje a pokryje poptávku po náročnějším studiu. Vnitřně diferencovaná výuka dle jejich slov může přilákat a udržet ty žáky, kteří přestup na víceletá gymnázia teprve zvažují. Učitelé i vedení škol se však téměř unisono shodli na tom, že víceletým gymnáziím lze konkurovat velmi těžce, nebot' pro žáky, respektive spíše pro jejich rodiče, představuje studium na gymnáziu primární volbu. Základním školám, ač se snaží uplatňovat různé inovativní strategie, např $v$ podobě vnitřně diferencovaného vzdělávání, se udržení žáků celkově nedaří.

Další téma, které reflektovali učitelé a zástupci škol odlišně, se týkalo určité vize částečné diferenciace. $V$ tomto příspěvku je na částečnou diferenciaci nahlíženo jako na jemnější formu dělení žákủ, a to z toho důvodu, že vzdělávání žáků neprobíhá trvale odděleně. Žáci se dělí jen na hlavní předměty, pouze na menši část dne. Jedná se tedy o jakousi střední cestu mezi trvalým rozdělováním žáků a společným vzděláváním. Jakým způsobem tedy na vnitřně diferencovanou výuku nahlížejí učitelé a vedení škol? Učitelé k diferenciaci přistupují jako k efektivní a pohodlnější formě vzdělávání žáků obdobných schopností. „Já, kdybych si mohla vybrat, tak bych takto chtěla učit ve všech hodinách, vyhovuje mi to po všech stránkách, je tam míň dětí ve třídě, stihnu se věnovat za tu hodinu všem, navíc jsou rozděleni výkonnostně, takže i příprava se mi dělá lépe, $v$ těch společných hodinách, tam je ruch, ti šikovní se nudí, otravují a na ty slabší tam zase nemám toliko prostoru," uvedla výstižně učitelka Anna. Z její citace je zjevné, že spíše inklinuje k možnosti žáky trvale dělit a od aktuálního trendu společného vzdělávání se odklání. Argumentuje výhodami, které jí dělená výuka nabízí. Obdobně se vyjadřovali i další učitelé. Vedení škol vedle toho považuje částečnou diferenciaci za „zlatou střední cestu" mezi odděleným a společným vzděláváním. Jeden z důvodů je i ten, že někteři zástupci ředitelů měli výukovou zkušenost se vzděláváním žáků v trvale odlišných skupinách, jsou si tudíž vědomi úskalí, která vnější diferenciaci provází. Zástupkyně Claudie ostatvě uvedla:

My jsme to jednoho času měli tak, že ta dělená výuka probíhala po všechny hodiny, byli děleni na tři skupiny. (...) A ta nejlepší skupina pak docela utekla té poslední skupině, a to byl pak docela problém, už jen kvůli inspekci, že ty děcka nejsou na stejné úrovni a v těch slabých skupinách se strašně špatně učilo. Nebyl tam ten tahoun, nebyla tam ta motivace. Zase ty děcka, když nevidí ty dobrý, tak mají 
ty průměrný děcka pocit, co jsou v té slabší skupině, že jsou jako dobří, ale jsou vlastně průměrní, a to je taky nebezpečná věc, takže úplně bych to na všechny hodiny, nebo nemyslím si, že je to dobře vybrat ty dobrý a ty špatný na všechny hodiny toho předmětu nebo dokonce na celou docházku ve všem. Takhle, jak to máme, tak jdem trošku po vlně té inkluze aspoň.

Z citací vyplývá, že učitelé ve vedoucí pozici nahlížejí na vnitřně diferencovanou výuku z širšího hlediska. Vzdělávání žáků v homogenních skupinách oceňují, avšak jsou si vědomi následků trvalé selekce žáků. Částečnou diferenciaci žáků tedy považují za možnost, jak se úskalím vyhnout, a zároveň jako možnost, jak se přiblížit k inkluzivním trendům. To, že se učitelé ve vedoucí pozici k částečné diferenciaci staví komplexněji, lze přisoudit tomu, že nesou zodpovědnost za výsledky žáků na jednotlivých školách, kdežto učitelé spíše přemýšlejí nad výsledky svojí vlastní výuky.

\section{Diskuze a závěr}

Předložená studie je věnována tématu vzdělanostních nerovností, které patří $\mathrm{v}$ České republice $\mathrm{k}$ nadprůměrným. Výsledky mezinárodních šetření ukazují, že za hlavní příčinu lze považovat rozdílnou úroveň př́ležitostí a aspirací k učení (PISA, 2012; MŠMT, 2013), která je silně determinovaná rodinným zázemím a strukturou vzdělávacího systému (ČŠI, 2013; Šojdrová et al., 2014). Zároveň je doloženo, že vnější/trvalá diferenciace nevede k lepšímu průměrnému výsledku, nýbrž vede $\mathrm{k}$ větším rozdílům mezi žáky $\mathrm{z}$ různých vzdělávacích proudů (Gamoran, 1992; Hanushek \& Woessman, 2005). Vzhledem k tomu, že k trvalému rozdělování žáků dochází velmi brzy, zvyšuje se také diferenciace výsledků žáků výběrových a nevýběrových větví (Straková, 2010).

Vzhledem k vlastnostem diferencovaného vzdělávacího systému je snahou tvůrců vzdělávacích politik směřovat $\mathrm{k}$ takovému systému, $\mathrm{v}$ němž nebude docházet v rámci povinného vzdělávání k žádné trvalé diferenciaci (Straková, Simonová, \& Friedlaenderová, 2019). Jedná se však o určitou vizi, jejíž naplnění je prozatím problematické. Realističtějším řešením je trvalé rozdělování žáků spíše oslabit a směřovat k vnitřně diferencovanému základnímu vzdělávání, které umožní optimální rozvoj všech žáků - tedy žáků nadaných i žáků zdravotně či sociálně znevýhodněných. Překvapivě však chybí výzkumná evidence, která by mechanismus částečné diferenciace na úrovni českého základního vzdělávání mapovala. 
Předložená studie se proto snažila zachytit kontext vnitřně diferencované výuky na základních školách, které se rozhodly pro kombinaci heterogenního a homogenního uspořádání. To znamená, že v hlavních předmětech jsou žáci rozdělováni na některé vyučovací hodiny do dvou skupin. Z perspektivy učitelů a částečně i vedení škol tato studie vysvětlovala, proč se školy rozhodly jít cestou částečné diferenciace, a současně popisovala, jak částečná diferenciace funguje v šestém ročníku základní školy.

Výsledky ukázaly, že jedním z důvodu pro zavedení částečné diferenciace je podle učitelů početnost šestých ročníků, jejichž kolektiv je z hlediska výkonu údajně značně heterogenní. Díky diferenciaci žáků na dvě výkonnostní skupiny - skupinu výkonnějších a méně výkonných žáků - učitelé pocit’ují, že mohou snáze přizpůsobovat výuku jejich potřebám. K rozdělení však dochází na začátku školního roku, a proto může být pro učitele problematické zjistit skutečný výkon každého žáka. Jedná se navíc o žáky šesté třídy, obyčejně se s nimi druhostupňoví učitelé setkávají prvně. Učitelé mají poměrně krátkou dobu na to, aby vyhodnotili, jak žáky rozdělit. Kritérium výkonnosti přitom mají stanovené ještě před tím, než se s novou třídou vůbec setkají. Učitelé tak spíše předpokládají, že budou mezi žáky značné rozdíly ve výkonech, než že by jejich rozhodnutí podléhalo dlouhodobějšímu pozorování. Výsledky tedy poukazují na to, že dělit žáky podle kvantitativního kritéria může být problematické i v případě částečné diferenciace. Současné výzkumy totiž nahlížejí kriticky na dělení žáků podle akademických schopností do trvalých drah (např. Ireson et al., 2002). Kriticky hodnotí např. právě to, že jsou žáci často rozřazeni špatně, nebo že žáci skupiny nemění, ani když dojde ke změně v jejich výkonnosti (Ireson et al., 2002). To, že žáci třídy nemění, lze vysvětlit tím, že jsou rozděleni trvale na všechny předměty. Přechody mezi třídami jsou tak komplikované, obzvláště pak přechody ze třídy méně výkonné do třídy výkonnějších žáků. Částečná diferenciace by měla přechod mezi skupinami usnadnit, jelikož se dělí žáci stejné třídy, a to pouze na určité předměty $\mathrm{v}$ některé dny v týdnu. Výsledky předloženého šetření nicméně tento benefit částečné diferenciace nepotvrzují. Učitelé připouštějí částečnou propustnost, nicméně pouze směrem dolů. Možnost přechodu ještě více znesnadňuje organizační zajištění diferenciace. Výuka probíhá paralelně, tzn. v jedné skupině žáků se vyučuje český jazyk, současně se v druhé skupině vyučuje matematika. Hypoteticky vzato: pokud by se tedy zjistilo, že se změnil výkon žáka pouze $v$ jednom předmětu, musel by být automaticky přeřazen také 
v předmětu druhém. To by vysvětlovalo, proč žáci mění skupiny spíše sporadicky (i když učitelé změny ve výkonech některých žáků reflektovali).

Navzdory diskutabilnímu dělení žáků výsledky ukazují, že si učitelé možnost částečného rozdělování žáků do homogenních nebo spíše homogenizovaných skupin (žáci ani v těchto skupinách nejsou stejní) pochvalují. Mohou tak snáze přizpůsobovat výuku potřebám žáků $v$ daných skupinách. Výuku diferencují podle obsahu učební látky, tempa učení, ale také podle předpokládaných schopností žáků v jednotlivých skupinách. Žáky umístěné ve výkonově lepší skupině učitelé považují za potenciální gymnazisty, výuku se tedy snaží připravit kognitivně náročnější. Vedle toho od žáků umístěných ve skupině méně výkonné mají učitelé daleko menší očekávání, výuku koncipují tak, aby žáci dostáli alespoň základního standardu.

Tyto nálezy evokují známý fenomén sebenaplňujícího se proroctví (Brophy, 1983; Rosenthal \& Jacobson, 1968). Učitelé vnímají vlastnosti žáků, na základě čehož pak se žáky ve výuce jednají. Žáci chování učitelů sdílejí a přizpůsobují jemu svoje chování (Friedrich et al., 2015). V předložené studii tento fenomén funguje tak, že učitelé cíleně rozdělí žáky podle výkonu na dvě skupiny. Na základě očekávání určitých schopností žáků si připraví výuku, v ní potom se žáky jednají podle vytvořeného úsudku. To znamená, že se žáky, s nimiž mají učitelé spojena vysoká očekávání, mohou interagovat častěji a jiným způsobem než se žáky, které vnímají jako akademicky slabší. Následkem sebenaplňujícího se proroctví může být v kontextu této studie skutečnost, že žáci ve výkonnější skupině získávají kvůli pozitivnímu očekávání ze strany učitelů více př́ležitostí $\mathrm{k}$ učení a více se naučí. Vedle toho žáci z méně výkonné skupiny zvládnou přinejlepším základní učivo.

Vzhledem k tomu, že částečná diferenciace kombinuje heterogenní a homogenní seskupování žáků, lze předpokládat, že rozdíly ve výkonech žáků nemusejí být natolik markantní jako v př́ípadě trvalého rozdělování žáků do odlišných větví, na což upozorňují např. Gamoran a Mare (1989). Výsledky ovšem ukazují, že se tomuto požadavku nedaří prakticky dostát, nebot' výuka v heterogenní třídě je přizpůsobena žákům jinak patřícím do méně výkonné skupiny. Žáci z výkonnější skupiny se ve společných hodinách nudí, což potvrzují výsledky studie, která mimo jiné popisovala, jak se žákům v diferencované a nediferencované hodině daří (Navrátilová, 2019). Učitelé s těmito žáky interagují v př́ípadě, kdy je potřeba posunout výuku tzv. vpřed. 
Výsledky studie dále ukázaly, že se učitelé a zástupci v určitých názorech týkajících se vnitřně diferencované výuky rozcházejí. Reflektováno bylo téma konkurence jejich škol s víceletými gymnázii. Zatímco vedení považuje vnitřně diferencovanou výuku za strategii, kterou lze udržet stávající žáky na základních školách, učitelé jsou v tomto ohledu skeptičtější. Učitelé na vnitřně diferencovanou výuku nahlížejí jako na efektivní a pro ně pohodlnější způsob, jak vyučovat v menší skupince žáků obdobných schopností. Vedle toho společná výuka všech žáků v kmenových třídách je pro učitele v mnoha ohledech náročná. Pokud by si mohli vybrat, zda žáky vyučovat trvale odděleně v menších skupinách, anebo v kombinaci s heterogenní výukou, volili by první možnost. Vedení škol na vnitřně diferencované vzdělávání nahlížejí obšírněji. Jeho členové jsou si vědomi, díky zkušenostem s určitými typy vnější diferenciace praktikovanými v minulosti na jejich školách, následků, které z trvalé selekce žáků vyplývají. Kombinaci heterogenní a homogenní výuky považují za možnost, jak se přiblí̌zit k myšlence společného vzdělávání.

Závěrem lze shrnout, že se vnitřně diferencovaná výuka částečně odchyluje od toho, jak je teoreticky vymezena např́č různými studiemi (např. Greger, 2004; Kasíková \& Straková, 2011; Hornby \& Witte, 2014) či ve strategických dokumentech (MŠMT, 2013). Ve výsledku funguje spíše jako další forma dělení žáků, tudíž nekompenzuje úskalí plynoucí z vnější diferenciaci. Naopak, spíše tato úskalí kopíruje, a myšlence společného vzdělávání se tak vzdaluje. Vzhledem k tomu, že je jedním ze strategických cílů vzdělávací politiky ČR do roku 2030+ oslabit tlak na vnější neboli trvalou diferenciaci školní soustavy (Veselý et al., 2019) a posílit vnitřně diferencovanou výuku, je nutné znát perspektivu učitelů, kteří se snaží vydaná opatření zavádět do praxe. Jejich zkušenosti, postoje i přesvědčení mohou poskytnout tvůrcům vzdělávací politiky zpětnou vazbu na to, zda se daří realizovat částečně diferencované vzdělávání tak, aby bylo v souladu s myšlenkou inkluze. Domnívám se, že výpovědi učitelů mohou posloužit také ostatním vyučujícím z dalších škol, kteř́i možnost částečně diferencovaného vzdělávání teprve zvažují.

Navzdory př́slibům předložené studie je třeba upozornit na případné limity výzkumného šetření. První slabinu spatřuji ve velikosti vzorku, nebot' data byla získána pouze na pěti základních školách. Jedná se nicméně o všechny brněnské školy, které v době sběru dat uvedly, že využívají částečně diferencované výuky. Přesto tato data nelze zobecňovat na všechny školy. S tímto faktem souvisí další úskalí, a sice že data byla sesbírána v uplynulých dvou letech. Je možné, že ve školním roce 2019/2020 se počet škol i způsob 
realizace částečné diferenciace mohly změnit a pravděpodobně i změnily už jen z toho důvodu, že jsou školy stále intenzivněji vystavovány požadavku vzdělávat všechny žáky společně. $V$ návaznosti na limity této studie se domnívám, že je potřeba se částečné diferenciaci věnovat nadále. $V$ českém prostředí prozatím nemáme $\mathrm{k}$ dispozici dostatek kvantitativních výzkumů, které by umožnily změřit přidanou hodnotu částečně diferencovaného vzdělávání. Chybí také kvalitativní, zejména longitudinální výzkumy, které by umožnily podat komplexnější a hlubší obraz o tom, jak funguje tato forma dělení žáků v českých (nejen) základních školách.

\section{Literatura}

Bittnerová, D., Doubek, D., \& Levínská, M. (2011). Funkce kulturních modelů ve vzdělávání. Praha: UK.

Brophy, J. E. (1983). Research on the self-fulfilling prophecy and teacher expectations. Journal of Educational Psychology, 75(5), 631-661.

Burns, A. (2010). Doing action research in English language teaching: A guide for practitioners. New York: Routledge.

Butler, J. S., Carr, D. A., Toma, E. F., \& Zimmer, R. (2013). Choice in a world of new school types. Journal of Policy Analysis and Management, 32(4), 785-806.

Cohen, L., Manion, L., \& Morrison, K. (2007). Research methods in education. London: Routledge.

Davies, J., Hallam, S., \& Ireson, J. (2010). Ability grouping in the primary school: issues arising from practice. Research Papers in Education, 18(1), 45-60.

Echols, F., McPherson, A., \& Willms, J. (1990). Parental choice in Scotland. Journal of Educational Policy, 5(3), 207-222.

Friedrich, A., Flunger, B., Nagengast, B., Jonkmann, K., \& Trautwein, U. (2015). Pygmalion effects in the classroom: Teacher expectancy effects on students' math achievement. Contemporary Educational Psychology, 41(1), 234-243.

Fuchs, L. S., \& Vaughn, S. (2012). Responsiveness-to-intervention: A decade later. Journal of learning disabilities, 45(3), 195-203.

Gamoran, A. (1992). Is ability grouping equitable? Educational Leadership, 50(2), 11-17.

Gamoran, A., \&. Mare, R. (1989). Secondary school tracking and educational inequality: Compensation, reinforcement, or neutrality? The American Journal of Sociology, 94(5), 1146-1183.

Gill, P., Stewart, K., Treasure, E., \& Chadwick, B. (2008). Methods of data collection in qualitative research: Interviews and focus groups. BDJ online, 204(6), 291-295.

Greger, D. (2004). Koncept spravedlivosti a diferenciace žáků. In E. Walterová (Ed.), Úloha školy v rozvoji vzdělanosti (s. 362-370). Brno: Paido.

Greger, D., Chvál, M., Walterová, E., \& Černý, K. (2009). Názory českých rodičů a veřejnosti na časné rozdělování žáků. Orbis scholae, 3(3), 51-78.

Greger, D., \& Holubová, M. (2010). Postoje učitelů k časnému rozdělování žáků a jejich zkušenosti s přechodem žáků do víceletých gymnázií. Pedagogický časopis, 1(1), 85-101. 
Greger, D., Martinková, P., Drabinová, A., Chvál, M., \& Straková, J. (2017). Tisková zpráva o přidané hodnotě víceletých gymnázií na základě zjištění longitudinálního výzkumu CLOSE. Praha: UK. Dostupné z https://webcache.googleusercontent.com/search?q=cache:cYALgoGnasJ:https://www.pedf.cuni.cz/PEDF-865-version1-tz_close2017pridana_ hodnotavg_.pdf $+\& \mathrm{~cd}=1 \& \mathrm{hl}=\mathrm{cs} \& \mathrm{ct}=\mathrm{clnk} \& \mathrm{gl}=\mathrm{cz}$

Guill, K., Lüdtke, O., \& Köller, O. (2017). Academic tracking is related to gains in students' intelligence over four years: Evidence from a propensity score matching study. Learning and Instruction, 47, 43-52.

Hanushek, E. A., \& Woessman, L. (2005). Does educational tracking affect performance and inequality? Differences-in-differences evidence across countries. Ifo Working Paper No. 1

ČŠI. (2013). Hlavní zjištění PISA 2012. Praha. ČŠI. Dostupné z http://www.csicr.cz/ getattachment/248e6459-87e1-437f-88fb-5359de627099

Hornby, G., \& Witte, Ch. (2014). Ability grouping in New Zeland high schools: Are practices evidence-based? Preventing School Failure, 58(2), 90-95.

Ireson, J., Clark, H., \& Hallam, S. (2002). Constructing ability groups in th secondary school: Issues in practice. School Leadership and Management, 22(2), 63-176.

Kasíková, H., \& Straková, J. (Eds.). (2011). Diverzita a diferenciace v základním vzdělávání. Praha: Karolinum.

Kaščak, O., \& Betáková, E. (2014). Vzdelavanie a školovanie v ranom veku v socialne diferencovanej perspektive matiek. Sociológia, 46(1), 5-24.

Kutnick, P., Sebba, J., Blatchford, P., Galton, M., \& Thorp, J. (2005). The effects of student grouping: Literature review. Research Report 688. London: DfES.

Loveles, T. (1998). The tracking and ability grouping debate. Fordham report, 2(8), 2-37.

Lucas, S. R. (2001). Effectively maintained inequality: Education transitions, track mobility, and social background effects. American Journal of Sociology, 106(6), 1642-1690.

Matějů, P., \& Straková, J. (2003). Role rodina a školy v reprodukci vzdělanostních nerovností. Sociologický pohled na úlohu víceletých gymnázií ve světle výzkumu PISA 2000. Sociologický časopis, 39(5), 625-652.

McDonough, J., \& McDonough, S. (1997). Research methods for English language teachers. London: Arnold.

McKay, S. L. (2006). Researching second language classrooms. Mahwah: Lawrence Erlbaum Associates.

Miles, B. M., \& Huberman, A. M. (1994). Qualitative data analysis: An expanded sourcebook. Sage Publications.

Miovský, M. (2006). Kvalitativní př́istup a metody v psychologickém výzkumu. Praha: Grada Publishing.

Mouralová, M. (2013). Postoje českých učitelů k vnější diferenciaci žáků a možné hodnotové kořeny těchto postojů. Orbis scholae, 7(3), 11-26.

MŠMT. (2001). Národní program rozvoje vzdělávání v České republice: Bílá kniha. Praha: Tauris.

MŠMT. (2013). Strategie vzdělávací politiky České republiky do roku 2020. Dostupné z https:// www.msmt.cz/vzdelavani/skolstvi-v-cr/strategie-vzdelavaci-politiky-2020-1

MŠMT. (2018). Základní informace ke společnému vzdělávání. Dostupné z http://www.msmt.cz/ file/39369/ 
Navrátilová, J. (2019). Diferencovaná výuka jako cesta k žákovské participaci. Studia paedagogica, 24(1), 158-186.

Northey, S. S. (2005). Handbook on differentiated instruction for middle and high schools. New York: Routledge.

Obrovská, J. (2016). Frajeři, rapeři a propadlíci: etnografie etnicity a etnizace v desegregované školní trrídě. Sociologický časopis, 52(1), 53-78.

OECD. (2002). Educational policy analysis. Paris: OECD.

OECD. (2011). Education policy outlook. Czech Republic.

Patton M. (2002). Qualitative research and evaluation methods. Thousand Oaks: Sage.

Prast, E., Van de Weijer-Bergsma, E., Kroesbergen, E. H., \& Van Luit, J. E. H. (2018). Differentiated instruction in primary mathematics: Effects of teacher professional development on student achievement. Learning and Instruction, 54, 22-34.

Pressey, S. L. (1949). Educational acceleration: Appraisal of basic problems. Columbus: Ohio State University.

Rosenthal, R. \&, Jacobson, L. (1968). Pygmalion in the classroom: Teacher expectation and pupils' intellectual development. New York: Holt, Rinehart \& Winston.

Salchegger, S. (2016). Selective school system and academic self-concept: How explicit and implicit school-level tracking relate to big-fish-little-pondeffect across cultures. Journal of Educational Psychology, 108(3), 405-423.

Smale-Jacobse, A. E., Meijer, A., Hlems-Lorenz, M., \& Maulana, R. (2019). Differentiated instruction in secondary education: A systematic review of research Evidence. Frontiers in Psychology, 10, 1-23.

Smets, W., \& Struyven, K. (2018). Realist review of literature on catering for different instructional needs with preteaching and extended instruction. Education sciences, 8(3), 1-18.

Söderström, M., \& Uusitalo, R. (2010). School choice and segregation: Evidence from an admission reform. Scandinavian Journal of Economics, 112(1), 55-76.

STEM/MARK. (2009). Sociologický výzkum zaměřený na analýzu struktury postojů a očekávání veřejnosti k oblasti školství, výchovy a vzdělávání, část 2. Postoje rodičủ a žákủ ke vzdělávání. Dostupné z http://www.msmt.cz/vzdelavani/skolskareforma/postoje-a-nazory-verejnostiskolstvi-a-vzdelavani

Straková, J., \& Simonová, J. (2010). Výběr základní školy v ČR a faktory, které jej ovlivňují. Sociologický časopis, 51(4), 587-606.

Straková, J., Simonová, J., \& Friedlaenderová (2019). Postoje odborné a laické veřejnosti k inkluzivnímu vzdělávání v kontextu obecných postojů k vnější diferenciaci. Studia paedagogica, 24(1), 80-106.

Straková, J. (2010). Dopad diferenciace vzdělávacích příležitostí v povinném vzdělávání na vývoj nerovností ve výsledcích žáků v ČR po roce 2000. Pedagogika, 60(1), 21-37.

Straková, J., \& Greger, D. (2013). Faktory ovlivňující přechod žáků 5. ročníků na osmileté gymnasium. Orbis scholae, 7(3), 73-85.

Straková, J., \& Simonová, J. (2015) Výběr základní školy v ČR a faktory, které jej ovlivňují. In D. Greger, J. Simonová, \& J. Straková (Eds.), Spravedlivý start. Praha: UK.

Strauss, A., \& Corbinová, J. (1999). Základy kvalitativního výzkumu. Boskovice: Albert. 
Šojdrová, M., Bařinková, Z, Borkovcová, I., \& Dlouhý, R. (2014). Rovný přístup ke vzdělávání v České republice: situace a doporučení. Praha: ČŠI. Dostupné z http://www.vyzkum-mladez.cz/ zprava/1432571599.pdf

Tannenbergerová, M. (2016). Průvodce školní inkluzí. Praha: Wolters Kluwer ČR.

Tieso, C. L. (2003). Ability grouping is not just tracking anymore. Roeper Review, 26, 29-36.

Tomlinson, C. A. (2014). The differentiated classroom. Responding to the needs of all learners. USA: ASCD.

Vališová, A., \& Kasíková, H. (Eds.). (2007). Pedagogika pro učitele. Praha: Grada.

Veselý, A., \& Matějů, P. (2010). Vzdělávací systémy a reprodukce vzdělávacích nerovností. In P. Matějů, J. Straková, \& A. Veselý (Eds.), Nerovnosti ve vzdělávání. Od měření k řešení (s. 38-90). Praha: SLON.

Veselý, A., Fisher, J., Jabůrková, M., Pospíšil, M., Prokop, D., Sáblík, R., Stuchlíková, I., \& Štech, S. (2019). Hlavní směry vzdělávací politiky ČR do roku 2030+. Dostupné z https://www.msmt. cz/file/51582/

Walterová, E. (Ed.). (2011). Dva světy základní školy? Úskalí přechodu z 1. na 2. stupeň. Praha: Karolinum.

Wilkinson, S., Penney, D., \& Allin, L. (2016). Setting and within-class ability grouping: A survey of practices in physical education. European Physical Education Review, 22(3), 336-354.

Zacharias, N. T. (2012). Qualitative research methods for second language education: A Coursebook. United Kingdom: Cambridge Scholars.

Zákon č. 561/2004 Sb., o předškolním, základním, středním, vyšším odborném a jiném vzdělávání (školský zákon). Ministerstvo školství, mládeže a tělovýchovy.

\title{
Autor
}

Mgr. Jana Navrátilová, DiS., Masarykova univerzita, Filozofická fakulta, Ústav pedagogických věd, Arne Nováka 1, 60200 Brno, e-mail: navratilova@mail.muni.cz

\section{Together, yet still separately: Differentiated instruction in lower secondary school}

\begin{abstract}
The paper analyses current situation of ability grouping (the use of ability grouping only for specific curriculum areas, students spend most of their time in mixed-ability classes) in lower secondary schools in Brno. The theoretical part describes the issue of differentiated education in the Czech Republic. Further it introduces the ability grouping system, which presents more delicate form of pupil separation. This study is designed as qualitative research. The data were gained from interviews with the school headmasters $(n=4)$ and the teachers $(n=6)$, who have direct experience with differentiated instruction. The results show that pupils are allocated into two homogeneous groups according to predetermined criterion - the criterion
\end{abstract}


of output. Teachers use intra class ability grouping to adapt their instruction to the easily diverse learning needs of students in their classrooms. The teachers modify their instruction with respect to learning content, learning time and their expectation about the abilities of the pupils in the selected groups. The data further shows that teachers and school headmasters differ in their opinions about certain topics concerning differentiated classroom.

Keywords: tracking, intra class ability grouping, differentiated instruction, equal learning opportunities, interviews, lower secondary school 